\title{
Translating Grand Challenges From Concept to Community: The "Communities in Action" Experience
}

\author{
Kevin P. Haggerty University of Washington \\ Vaughnetta J. Barton University of Washington \\ Richard F. Catalano University of Washington \\ Margaret L. Spearmon University of Washington \\ Edith C. Elion Atlantic Street Center \\ Raymonda C. Reese Therapeutic Health Services \\ Edwina S. Uehara University of Washington
}

\begin{abstract}
This article provides an example of how one social work school created a community partnership to translate grand challenges from concept to concrete local projects to meet Grand Challenges for Social Work goals. The Grand Challenge to Ensure Healthy Development for All Youth proposes that we have made sufficient scientific advances to-within a decade-reduce the incidence and prevalence of behavioral health problems among children, adolescents, and young adults by $20 \%$, and to reduce the incidence of racial and socioeconomic disparities in behavioral health problems by $20 \%$. In 2014, faculty and students from the University of Washington School of Social Work began working with a broad coalition of community-based agencies, governmental partners, and funding agencies to tackle this grand challenge at the community level. The coalition adopted Communities That Care, a tested model for developing prevention infrastructure in communities by building the capacity of community coalitions to assess and prioritize local need, match need to evidence-based prevention programs, and support quality implementation with sufficient reach to change behavioral health problems at the community level. The collaboration chose the name Communities in Action for this effort. This article illustrates how Communities in Action exemplifies grand challenges implementation and highlights lessons learned that can be applied to other grand challenges efforts.
\end{abstract}

KEYWORDS: grand challenges, prevention, community mobilization

doi: $10.1086 / 690561$

Journal of the Society for Social Work and Research, Volume 8, Number 1. 2334-2315/2017/0801-0009/\$10.00 c) 2017 by the Society for Social Work and Research. All rights reserved. 
T

he Grand Challenges for Social Work adopted by the American Academy of Social Work and Social Welfare (Hawkins et al., 2015a, 2015b; Uehara et al., 2013) reflect a powerful approach to tackling complex, uncertain, seemingly intractable social problems of our time. Many of these challenges are not new; some have been thorny issues in the field of social work for a while. Now the American Academy of Social Work and Social Welfare is challenging the field to move forward using science, practice, innovation, and impact to create substantive change not only in how we practice social work, but how we develop the future workforce. The grand challenges are appropriate for the social work field because they elevate and focus energy and leadership on key issues while necessitating crossdisciplinary and cross-sector collaborations (Uehara et al., 2013).

There is a need to understand much more about effective strategies for carrying out grand challenges work-strategies that link distributed and collective action to effective grand challenges solutions and collective impact (Ferraro, Etzion, \& Gehman, 2015). Responsibility, authority, and resources are distributed across institutions (professions, agencies, organizations, and social sectors), and no individual or institution can solve the grand challenges alone. Consider this example: If we are to dramatically improve high school and college graduation rates for the nation's most disadvantaged youth, then we must create comprehensive strategies to effectively strengthen families and neighborhoods, and to promote healthy, prosocial bonds amongyouth, families, schools, and communities. Community-based prevention programs, many developed by social work prevention scientists, offer some of our most promising vehicles for successfully meeting this national priority (Hawkins, Kosterman, Catalano, Hill, \& Abbott, 2005; Hawkins et al., 2012).

This article focuses on how grand challenges efforts can be taken up at the local community level, and it describes our effort to address specific and heterogeneous needs of a local community while simultaneously contributing to social work's grand challenges aspirations for national and international impact. We provide a promising case example of using a science-based collective-impact model, Communities That Care (CTC; Brown, Hawkins, Arthur, Briney, \& Fagan, 2011; Feinberg, Greenberg, Osgood, Sartorius, \& Bontempo, 2007; Feinberg, Jones, Greenberg, Osgood, \& Bontempo, 2010; Haggerty \& Shapiro, 2013; Hawkins, Oesterle, Brown, Abbott, \& Catalano, 2014; Hawkins et al., 2009; Hawkins et al., 2012; Kuklinski, Briney, Hawkins, \& Catalano, 2012; Kuklinski, Fagan, Hawkins, Briney, \& Catalano, 2015), as a collaborative strategy between a social work school and a local urban neighborhood to address the Grand Challenge to Ensure Healthy Development for All Youth by Unleashing the Power of Prevention (Hawkins et al., 2015a, 2015b). Our strategy involved leveraging structural, scientific, human, and educational capital of the University of Washington School of Social Work to form a strong base for school-community partnership. In addition to using the CTC model, this included three important elements. First, we actively involved agencies with whom we al- 
ready had strong relationships as field placement sites. They informed the process and were important champions and key leaders. Second, the school made resources available to support the convening process to achieve and sustain momentum. We ensured staffing was available so we could build on successes. Finally, we strategically involved students to achieve the goals of CTC (locally named Communities in Action) and their respective educational goals, offering students deep learning and practice opportunities and credits toward their state prevention practitioner certificate.

\section{Ensure Healthy Development for All Youth by Unleashing the Power of Prevention}

When it comes to giving young people a healthy start in life, the United States faces very different challenges than it did just 30 years ago. As a result of successful efforts to combat infectious diseases, and increased investments in child health, the major contributors to mortality during adolescence and young adulthood have shifted from communicable to noncommunicable diseases (Catalano et al., 2012). For adolescents, behavioral health problems are implicated in this shift.

Behavioral health problems like substance use, violence, risky driving, mental health problems, and risky sexual activity now are the leading causes of mortality for people ages 15 to 24, accounting for $74 \%$ of all deaths (Hoyert \& Xu, 2012). Behavioral health problems reflect and perpetuate social inequalities. Different social groups-characterized by gender, race, ethnicity, citizenship, sexual orientation, and class-experience dramatically different levels of behavioral health. For example, the contribution of behavioral health problems for American Indians and Alaskan Natives accounts for almost $83 \%$ of all deaths, with suicide twice the rate of the general population; drug and alcohol overdose are two of the 10 leading causes of death, but these two causes are not in the top 10 for the whole population (Centers for Disease Control and Prevention, 2014).

Behavioral health problems that begin in childhood and adolescence take a heavy toll over a lifetime and have significant impacts on rates of economic independence, morbidity, and mortality (Hale \& Viner, 2012). These behavioral health problems are largely preventable, and preventing them in adolescence is likely to reduce mortality and morbidity worldwide. Promoting health among young people requires us to refocus to prevent behavioral health problems and improve the public health (Catalano et al., 2012).

A large body of scientific evidence over 40 years shows that behavioral health problems can be prevented. Prior to 1980 , few prevention programs for behavioral health problems had been tested, and virtually no effective prevention programs had been identified (Berleman, 1980; Janvier, Guthmann, \& Catalano, 1980). In part, this was because we did not have the research base to identify the risk and protective factors that predict these behavioral health problems, and public health has 
shown that addressing predictors through prevention programs is a plausible approach to prevention (Catalano et al., 2012; Coie et al., 1993; Lu \& Halfon, 2003). During the past 40 years there has been a large investment in longitudinal studies that have identified malleable individual and environmental risk factors that predict wide-ranging behavioral health problems (Catalano, Haggerty, Hawkins, \& Elgin, 2011; Farrington, 1995; Harrop \& Catalano, 2016; Hawkins, Catalano, \& Associates, 1992; Loeber, Farrington, Stouthamer-Loeber, \& Van Kammen, 1998; Stone, Becker, Huber, \& Catalano, 2012). Research also has identified individual positive attributes and protective environmental influences that buffer or minimize the adverse effects of exposure to risk (Kim, Gilman, Hill, \& Hawkins, 2016; Lerner, Almerigi, Theokas, \& Lerner, 2005; Luthar, 2003).

These discoveries laid the foundation for developing and testing new prevention programs. Over the past three decades, more than 60 prevention programs and policies have been found effective in rigorously controlled studies of interventions aimed at preventing behavioral health problems in children, adolescents, and young adults (Blueprints for Healthy Youth Development, n.d.; Catalano et al., 2012; Hingson \& White, 2014; O'Connell, Boat, \& Warner, 2009). These effective prevention programs and policies, or evidence-based programs (EBPs), have addressed several behavioral health problems, including anxiety and depression; autism; self-inflicted injury; risky sexual behaviors; unwanted pregnancies; obesity; risky driving; alcohol, tobacco, and other drug use; delinquent behavior, violence, and aggressive behavior; and school dropout (Hawkins et al., 2015b). Since many of these behavioral health problems are predicted by shared risk and protective factors, several prevention programs addressing these common predictors have produced positive effects on multiple behavioral health outcomes (Hale, Fitzgerald-Yau, \& Viner, 2014). It is important to note that young people exposed to the highest levels of risk-children and adolescents who often are disproportionately low income and/or youth of color-often benefit most from preventive interventions (Campbell, Ramey, Pungello, Sparling, \& Miller-Johnson, 2002; Clark, Cornelius, Kirisci, \& Tarter, 2005; Dodge et al., 2015; Hawkins et al., 2005; Hill et al., 2014).

The evidence of beneficial effects from EBPs is bolstered by cost-benefit analyses showing that prevention programs offer significant cost savings over alternatives such as incarceration or long-term treatment (Aos \& Drake, 2013; Aos et al., 2011). Evidence-based prevention also is critical to reining in the escalating costs of health care. If nothing is done, the cost of health care and lost productivity from preventable disease is projected to be $\$ 4.2$ trillion by 2023. Investing in prevention and early intervention could save as much as $\$ 1$ trillion annually (DeVol \& Bedroussian, 2007). Furthermore, because preventable disease has a disproportionate impact on poor and disadvantaged populations, promoting evidence-based prevention has the demonstrated potential to reduce health disparities in behavioral health problems and structural determinants of health (Hawkins, Kosterman, Catalano, Hill, \& Abbott, 2008). 
A critical mass of prevention science points to what's possible. The goal of the Ensure Healthy Development for All Youth Grand Challenge is to take preventive EBPs to scale, expanding them to achieve population-wide reductions in behavioral health problems. Scaling proven prevention approaches at the local, state, and national level can improve health and well-being, save lives, reduce the economic burden of preventable disease, and promote health equity. The Grand Challenge to Ensure Healthy Development for All Youth has two goals: (a) within a decade, reduce behavioral health problems among children and adolescents from birth to age 24 by $20 \%$; and (b) reduce racial and socioeconomic disparities in behavioral health by $20 \%$ over the same period. To achieve these goals, it will be necessary to build political will, infrastructure, funding, and workforce capacity to effectively implement and sustain at scale universal, selective, and indicated evidence-based prevention programs. Unleashing the Power of Prevention-one of two initiatives within the Ensure Healthy Development for All Youth challenge-has seven action steps to meet these goals:

1. Increase public awareness of the advances and cost savings of effective prevention programs that promote healthy behaviors for all.

2. Implement capacity-building tools that guide communities to assess and prioritize risk and protective factors, and select evidence-based prevention programs.

3. Increase infrastructure to support the high-quality implementation of prevention programs.

4. Monitor and increase access of children, youth, and young adults to effective prevention programs.

5. Create workforce development strategies to prepare practitioners for new roles in promotion and prevention programs.

6. Increase the percentage of all public funds that are spent on effective prevention programs.

7. All states establish criteria for prevention programs that are effective, sustainable, equity enhancing, and cost beneficial.

This challenge has led to a broad-based set of actions to unleash the power of prevention, including, (a) advocacy at the federal and state levels to increase public awareness and support for prevention, (b) public system conversations within states to build infrastructure to support EBP implementation with fidelity and sustainability, (c) advocacy to incorporate effective prevention programs for parents into reimbursable prevention services through the Affordable Care Act, and (d) creating a plan to build the capacity and size of the workforce to implement preventive EBPs. At the local level, building capacity to choose the right EBPs based on need, implement them with fidelity, and sustain them is being addressed through multiple federal, state, and community efforts. This requires a collective-impact strat- 
egy, with citizen scientists understanding local epidemiology of risk, protection, and behavioral health problems; prioritizing predictors and problems that create community malaise; and matching these priorities to effective prevention programs. One effective model to do this is CTC, developed by the Social Development Research Group at the University of Washington School of Social Work (UW SSW). This local impact model creates a partnership between UW SSW faculty, practicum agencies, practicum students, and community residents. Development of this innovation began in 2014 with the UW SSW's outreach to its practicum agencies serving disadvantaged populations at the community level.

University of Washington School of Social Work and Practicum Agency Inquiry The UW SSW engages more than 200 human-service agencies to provide practicebased learning opportunities to its students. Simultaneous to the launch of the social work grand challenges, the school conducted an inquiry of agencies serving disadvantaged populations in low-income areas of Seattle, WA. The UW SSW wanted to understand agency needs and how the UW SSW might further support them in addressing development of the social work workforce. This inquiry took place over a 9-month period. Practicum agencies responded openly and enthusiastically to the inquiry. Recurring themes included:

1. a need for UW SSW's assistance in the coordination of community services to promote healthy child and youth development;

2. a call for support to help agencies improve academic achievement and child well-being and to decrease child-related problems like abuse and neglect, unstable housing, youth violence, and other negative outcomes including substance abuse, mental health problems, and risky sexual behavior;

3. an interest in achieving deep community impact; and

4. an interest in examining and adopting evidence-based practice models in a strategic and coordinated way throughout the community.

To address the stated needs of our practicum agencies, we worked with the local community and determined that the science-based collective-impact approach, CTC, would address these needs and provide the opportunity for deeper community engagement.

\section{Using Communities That Care to Unleash Prevention}

CTC has been developed and refined over the past 25 years through a process of community-based participatory research with substantial input from communities across the United States and internationally (Fagan, Hawkins, Catalano, \& Farrington, in press) to achieve a proven public health impact (Brown et al., 2011; Feinberg et al., 2007; Feinberg et al., 2010; Hawkins et al., 2014; Hawkins et al., 2009; Haw- 
kins et al., 2012; Kuklinski et al., 2012; Kuklinski et al., 2015). The prevention system provides communities with tools to prevent behavioral health problems by assessing youth experience and prioritizing and matching empirically identified risk and protective factors with EBPs that affect predictors. The premise underlying CTC is that the prevalence of adolescent problem behaviors in a community can be reduced through this process if appropriate EBPs are delivered with fidelity to a sufficient proportion of the population. CTC is grounded in rigorous research from the fields of social work, public health, psychology, education, medicine, criminology, and organizational development. For communities moving toward a risk- and protective-factor approach to prevention, the CTC framework is a navigation device that guides citizen scientists to choose appropriate evidence-based prevention programs that meet their needs and fit the local culture. CTC also provides training and technical assistance to create strong, sustainable community coalitions.

\section{The Communities That Care Process}

The community capacity-building system is conducted in five phases. Phase 1 involves defining the community, identifying stakeholders, deciding the scope of the prevention effort, ensuring support for community collaboration, and addressing any community readiness issues. Phase 2 helps communities get organized by orienting key leaders and community decision makers (e.g., business owners, elected officials, religious leaders, philanthropists, media representatives, law enforcement, school superintendents, juvenile justice, and other public systems officials who control resources) and formalizing a diverse and comprehensive coalition of stakeholders to serve as the working group for CTC implementation. The coalition is led by a paid coordinator who may be a professional social worker with an interest or background in community organizing, systems change, or management and planning (Hawkins, Shapiro, \& Fagan, 2010). During Phase 3, the coalition develops a community profile of risk and protection by collecting data through the CTC Youth Survey, a school-based survey of a census sample of all 6th-, 8th-, 10th- and 12th-grade students in their community. The survey data are used to obtain estimates of the local levels of risk, protection, and problem behavior (Arthur, Hawkins, Pollard, Catalano, \& Baglioni, 2002). Using this data, communities prioritize risk and protective factors for community action. The community also collects data on what resources are already being used in the community to address prioritized risk and protective factors. During Phase 4, the coalition develops an action plan to address community service gaps by selecting programs, policies, and practices that address the prioritized risk and protective factors. CTC refers tested and effective programs meeting the standards of the Blueprints for Healthy Youth Development database of programs (www.blueprintsprograms.com). Phase 5 involves implementing and evaluating the selected prevention EBPs and reaching the target population with requisite levels of saturation to have community-wide impact. The system is guided 
by Milestones and Benchmarks that act as an implementation fidelity checklist for the CTC process.

CTC is guided by the social development model (Catalano \& Hawkins, 1996). The model hypothesizes that children learn patterns of behavior, whether prosocial or antisocial, from their social environment. Children are socialized through three processes (see Figure 1): (a) perceived and actual opportunities for involvement in activities and interactions with others, (b) skills for involvement and interaction, and (c) perceived rewards from involvement and interaction. When socializing processes are consistent, a social bond of attachment and commitment develops between the individual and the people and activities of the socializing unit. Once strongly established, the social bond inhibits behaviors that are inconsistent with the beliefs held and behaviors practiced by the socialization unit; behavior inhibition is accomplished through establishment of an individual's stake in conforming to the socializing unit's norms, values, and behaviors. CTC helps communities focus on strengthening protective factors that can buffer young people from problem behaviors and promote positive youth development.

Communities That Care Evidence of Impact

CTC's efficacy has been demonstrated in a randomized controlled trial involving 24 communities throughout the United States (Hawkins et al., 2014; Hawkins et al., 2012; Oesterle et al., 2015), as well as a quasi-experimental effectiveness trial in

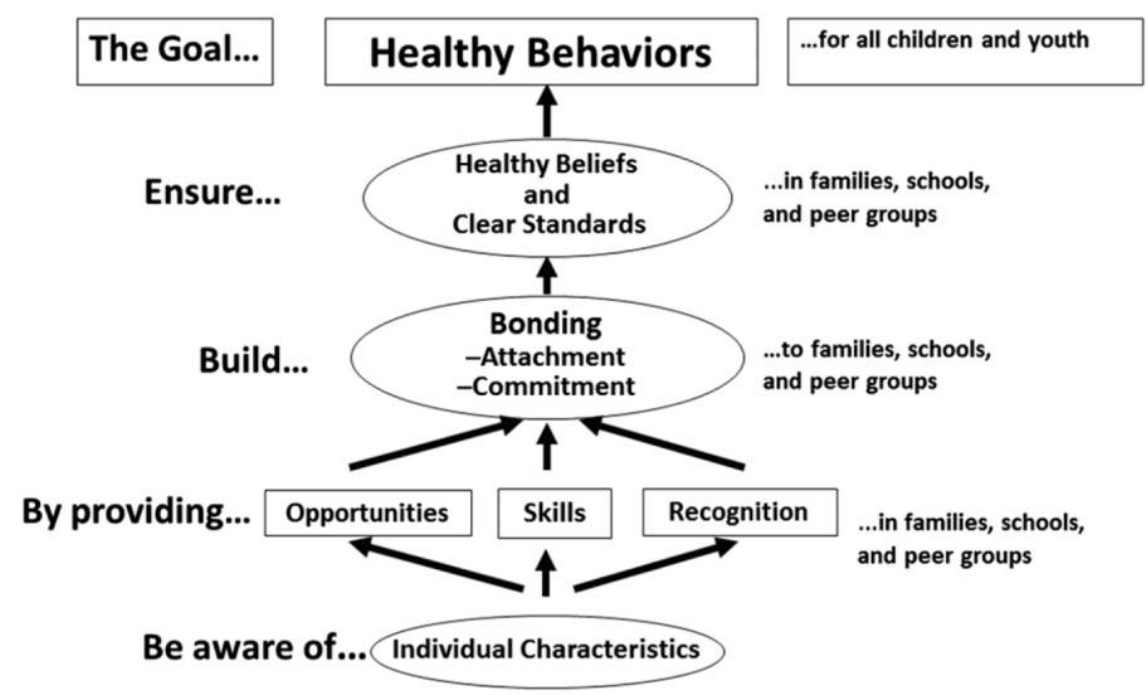

Figure 1. The social development model. 
Pennsylvania, where over 120 communities have implemented CTC (Feinberg et al., 2010). Both trials have shown that high-quality implementation of the CTC prevention system can be achieved using the CTC training and technical assistance system; that high-functioning prevention coalitions can be sustained over time; and that meaningful, significant, and sustained reductions in violence, delinquency, and substance use in youth can be realized. For example, in the 24-community trial, youths from a longitudinal panel in CTC communities have been shown to be $33 \%$ less likely to initiate smoking, $32 \%$ less likely to initiate alcohol use, $25 \%$ less likely to be delinquent by eighth grade compared to their control counterparts, and $25 \%$ less violent at 10th grade compared to controls. Additionally, independent cost-benefit analyses have shown that CTC returns $\$ 5.09$ per dollar invested through sustained abstinence from alcohol and tobacco use, through Grade 12 (Washington State Institute for Public Policy, 2016).

An Internet-based version of the CTC training system was developed to provide an integrated suite of tools that combines online training with telephone and inperson technical assistance. Introductory materials can be viewed at www.commu nitiesthatcare.net. These materials include a structure for engaging community stakeholders, a process for establishing a shared community vision, tools for assessing levels of risk and protection in communities, and processes for prioritizing risk and protective factors and setting specific, measurable community goals (Hawkins et al., 1992).

\section{Communities in Action}

The needs our practicum agencies expressed (noted previously) led to planning with a key group of practicum agencies to engage in the CTC process. Training and technical assistance to practicum agencies, students, and community residents provides capacity building. Increased capacity, in turn, creates citizen scientists who can plan and implement appropriate evidence-based prevention programs to prevent behavioral health problems at scale among youth in communities.

The UW SSW committed 5 years of support for a coordinator to facilitate the process both with the community and with Master of Social Work practicum students. The UW SSW acts as the backbone organization guiding agencies to move through the five phases of the CTC process. Following, we describe how this community/agency collaboration illustrates the action steps for Unleashing the Power of Prevention.

\section{Increase Public Awareness of Effective Prevention Programs:}

\section{Key Leaders Critical to Success}

The CTC process recognizes the important role of community key leaders, who are crucial to the success of community-level change. To be successful in this work it was important to bring energy and leadership on prevention while increasing cross- 
disciplinary and cross-sector collaborations among community nonprofit humanservice agencies and community residents. The core group of practicum agency directors first identified the influential people who support prevention initiatives and those who are well respected in the Southeast Seattle and Central Seattle communities. This diverse group of leaders was engaged to help increase public awareness of the impact of behavioral health problems and their potential reduction through implementation of effective prevention programs promoting healthy youth behaviors.

The role of the key leaders was to focus on the first Unleashing the Power of Prevention goal, increasing their awareness of the effectiveness and cost benefit of prevention so that they would invest in Communities in Action's selected EBPs in Phase 5. The decision makers of this collaboration project would be the core group members, labeled the Board Leadership Workgroup. Key leaders were connected to the project by attending one of two annual meetings to stay current with Communities in Action's progress, and they received individual briefings throughout the project phases when needed. Key leaders were asked to make a formal commitment to Communities in Action as a prevention initiative and to recommend others to champion this work and spread awareness of the effectiveness of prevention. The inaugural meeting concluded with attendees sharing the names of 51 emerging leaders as potential Communities in Action community board members. Communities in Action's key leaders are asked to

- support effective prevention and the promotion of child well-being and healthy youth development in Southeast Seattle and Central Seattle;

- promote the Communities in Action prevention process by informing others about this evidence-based work;

- help secure needed information and resources for implementing the community's chosen evidence-based prevention programs, policies, and practices; and

- attend one Communities in Action key leaders' meeting annually. The key leaders' meeting stimulated local media reports of this prevention effort, creating multiple opportunities for deeper conversations within the community.

Agency executives identify leadership role. To increase infrastructure to support the high-quality implementation of prevention programs, Communities in Action's Board Leadership Workgroup members focused on ways that additional practicum agencies and staff could participate in Communities in Action. Four strategies were developed to help build capacity in Southeast Seattle and Central Seattle. First, founding members identified program staff who were considered emerging leaders to actively participate on the community board. Second, the founding members of 
the Board Leadership Workgroup advanced their working relationships with current staff, mentored staff from other agencies, and served as a resource for Master of Social Work students. Third, the UW SSW worked closely with the Board Leadership Workgroup. Fourth, the Board Leadership Workgroup served as a public relations committee and a resource to the UW SSW.

\section{Implement Capacity-Building Tools That Guide Communities to Assess} and Prioritize Risk and Protective Factors, and Select Evidence-Based Prevention Programs

Building a community board. The Communities in Action board used the CTC tools to build the capacity to develop an effective community board and to assess risk, protection, and evidence-based programs in the community. Community board members were recruited by the Board Leadership Workgroup from the list of key leader nominees. The CTC community board orientation training was conducted, and workgroups were formed to take advantage of special skills and interests of board members in three areas: data analysis, assessment and evaluation, and youth and family (see Figure 2).

The Communities in Action community board consists of 20 community members who live or work in Southeast Seattle and Central Seattle and represent practicum agencies, public health programs, schools, residents, and youth-serving organizations. The board participated in a capacity-building orientation, which resulted in the creation of a collective vision: Our vision is that our communities are thriving be-

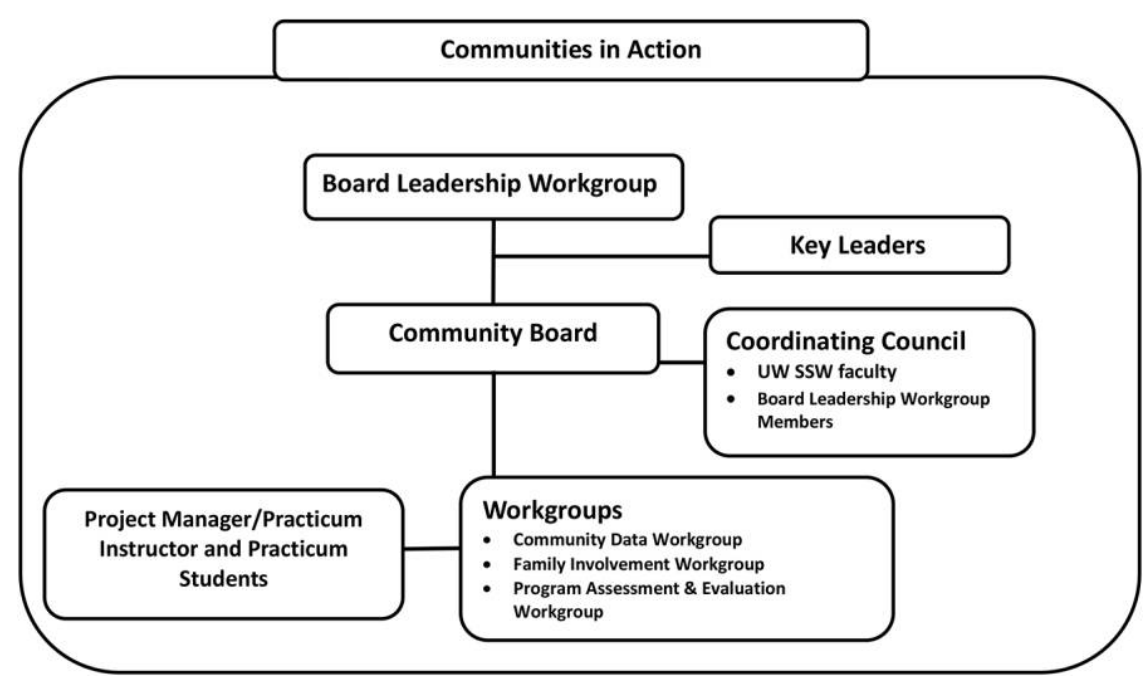

Figure 2. The Communities in Action organizational chart showing project manager/practicum instructor and practicum student roles. UW SSW = University of Washington School of Social Work. 
cause they support and build strong young people and families who are empowered, connected, educated, and have meaningful opportunities for generations to come.

Working closely with the Community Data Workgroup, practicum students accessed and analyzed community epidemiology data from the 2012 and 2014 Healthy Youth Survey for Southeast Seattle and Central Seattle 6th-, 8th-, and 10th-grade students. This survey provides easy-to-interpret epidemiological data, aggregated at the school level, on risk, protection, and behavioral health problems. Acting as consultants, practicum students presented their findings to the Community Data Workgroup for review and recommendation to the community board. Through a series of CTC workshops, the Communities in Action community board identified three risk factors as priorities based on the data on risk, protection, and behavioral health problems reviewed: (a) laws and norms favorable to drug use, (b) early initiation of antisocial behavior, and (c) academic failure. The community board also identified three protective factors: (a) community opportunities for prosocial involvement, (b) family opportunities for prosocial involvement, and (c) family rewards for prosocial involvement. The board also identified mental health (including substance use), and violence and aggression as the two behavioral issues to address.

Evidence-based program selection. The community board identified three tested and effective programs to address community priority risk and protective factors and the behavioral health outcomes of mental health, and violence and aggression. Using the Blueprints for Healthy Youth Development database of prevention EBPs, the Communities in Action community board examined tested, effective prevention programs that addressed their priorities and assessed fit of these programs with local community values and preferences. They chose to implement: (a) Guiding Good Choices, a 5-week family engagement program designed for parents of youths age 9 to 14 years; (b) The Incredible Years, a 12-week course for parents of youths age 0 to 5 years; and (c) LifeSkills Training, a school-based curriculum offered to sixthgrade students over the course of 3 years.

\section{Increase Infrastructure to Support the High-Quality Implementation of Evidence-Based Prevention Programs}

The Communities in Action board also conducted a comprehensive resource assessment to determine whether local agencies were using evidence-based preventive programs to address priority risk and protective factors. After assessing the 168 programs and agencies serving Southeast Seattle and Central Seattle, the Program Assessment \& Evaluation Workgroup identified that

- there were some evidence-based programs currently being implemented in Southeast Seattle and Central Seattle, but not at scale nor sustainably (they most often were funded by one to two grants); 
- most programs addressing the priority risk and protective factors had not been evaluated;

- there was a need for collaboration between larger agencies and culturally based grassroots organizations; and

- there was a need to build capacity with culturally diverse staff to deliver evidence-based programs with fidelity.

The board used these findings to advocate for locally supported coordination and sustainability of evidence-based prevention services, and the need for capacity building in agencies to implement the chosen tested, effective prevention approaches.

The project manager worked with a Board Leadership Workgroup agency director to secure pilot funding to demonstrate capacity to implement Guiding Good Choices. Through county and state applications, Communities in Action received funding for four Guiding Good Choices facilitators, child-care providers, manuals, customized training, and participant manuals and supplies. From reviewing the application, to securing the facilitators, to submitting performance reports, UW SSW practicum students and faculty assisted the practicum agencies in securing and administering implementation of this five-session program.

Pilot implementation of The Incredible Years was completed with local funds allocated to one of the Board Leadership Workgroup practicum agencies. A state grant from the Office of Superintendent of Public Instruction was secured to pilot LifeSkills Training in middle schools in Southeast Seattle and Central Seattle.

\section{Monitor and Increase Access of Children, Youth, and Young Adults to Effective Prevention Programs}

The Communities in Action community board drafted community-level outcomes to help define the desired changes for the Southeast Seattle and Central Seattle communities and to describe the required level of scale for the chosen evidencebased prevention programs to demonstrably change priority risk, protection, and behavioral health problems in the Communities in Action catchment area. Communities in Action has a goal to serve 200 families through Guiding Good Choices; 800 families through The Incredible Years; and 1,200 middle school students through LifeSkills Training between January 1, 2016, and December 31, 2017. Although these three prevention programs have been offered previously in Southeast Seattle or Central Seattle, implementation fidelity and saturation at the levels intended to have community-wide impact had not been robust. Expanding evidencebased programs required meetings with human-service organizations to further explore the barriers faced when implementing tested and effective programs. To chronicle its plans and the capacity-building role, the community board created a community action plan. 


\section{Create Workforce Development Strategies to Prepare Practitioners}

for New Roles in Promotion and Preventive Interventions

Communities in Action broadens social work students and practicum agencies to adopting scientifically supported prevention methods that improve public health (Austin, 1983; Van Pelt, 2009). The challenge in preparing practitioners for new roles in prevention is to emphasize the deep history of social work's focus on community impact, with an emphasis on prevention, to promote community conditions that foster well-being (Haggerty \& Shapiro, 2013).

Practicum student involvement. The Communities in Action model provides a rich learning experience for social work students. Practicum students focus on community organizing and community assessment, working with the coalition to recruit board members; assess and prioritize risk, protection, and behavioral health problems of youth; and assess existing evidence-based resources addressing priorities. The practicum experience is designed to build a solid workforce with a deep understanding of prevention science, including community epidemiology, community organizing, evidence-based prevention, and collective impact. The practicum provides macro and mezzo opportunities in the first 1 to 2 years and micro experience in subsequent years as evidence-based prevention programs are implemented in various community settings. Practicum students are encouraged to pursue a prevention certificate offered through the UW SSW. Along with elective studies, practicum students gain assistance in qualifying for multistate applicable prevention certification.

UW School of Social Work faculty. Throughout the five phases of CTC, it became evident that a critical role of UW SSW faculty associated with this effort was to serve as a convener, contributing to several Unleashing the Power of Prevention action steps: increasing public awareness of the effectiveness and cost effectiveness of prevention; advocating for increasing funding for prevention EBPs; advocating for EBP standards at the city, county, and state level; and advocating for building local practicum agency capacity and local infrastructure for prevention. Finally, engaging 12 practicum students over 2 years has helped to build the workforce needed to unleash the power of prevention. Further, working with Communities in Action allowed the UW SSW to serve as a community convener in tandem with member agencies to accomplish these action steps.

Social work practicum agencies. Following the CTC model, several strategies have been used to prepare practitioners for new roles in promotion and prevention programs. Capacity building activities have: (a) deepened the community's understanding of prevention science; (b) facilitated the creation of a common vision; and (c) engaged participants in using data to set priorities, inform decision making, articulate impact goals and action steps, and then align resources to implement effective and tested prevention programs. State and county funds facilitated the purchase of curriculum materials and staff training for three evidence-based prevention programs. 
Active student involvement through the practicum establishes a career pipeline for competent future social work professionals to enter the community as leaders in prevention practice. This strategic approach also has fostered the development of partnerships with funders and created new alliances committed to ensuring healthy development for all youth.

\section{Lessons Learned: Going to Scale}

Although the Communities in Action model is just beginning to scale in Southeast Seattle and Central Seattle, the goal is to advocate for taking this local exemplar statewide. Communities in Action provides a local example of how a social work school can implement local strategies to support the Grand Challenge to Ensure Healthy Development for All Youth. Communities in Action is a worthy investment because it is the perfect fit between grand challenges goals and perceived needs of practicum agencies, students, and communities. The potential of expanding this approach to 50 Washington State communities is the aspirational goal that could achieve reductions in behavioral health problems by $20 \%$ and close the disparity gap in behavioral health outcomes by $20 \%$ statewide in 10 years.

From its inception, this collective-impact project was designed as a learning opportunity. This innovative project requires all stakeholders to understand the components of the CTC model. The ability to adapt the model to the realities of the practicum agencies and student training needs shows the flexibility of CTC. Within this collaboration, the partnership with the UW SSW Office of Field Education expanded, providing a mutual benefit to practicum agencies and practicum students.

The implementation has yielded several important lessons in three broad areas that can inform other applications of this effort to promote grand challenges: (a) developing community stakeholder coalitions, (b) capacity building for the adoption and implementation of evidence-based prevention, and (c) university-studentcommunity partnerships.

\begin{tabular}{|l|l|l|}
\hline \multicolumn{1}{|c|}{ Micro Level } & \multicolumn{1}{|c|}{ Mezzo Level } & \multicolumn{1}{c|}{ Macro Level } \\
\hline - Client interviews & - Plan, organize, and lead or co-lead & - Program planning \\
- Case management & education and/or therapy groups & - Program evaluation \\
- Assessments & - Agency assessment & - Policy analysis \\
preventive programs & - Multidisciplinary activities & - Legislative activities \\
& & - Community organizing \\
& & - Coalition development \\
& & - Grant writing \\
\hline
\end{tabular}

Figure 3. Example of practicum activities proposed to human-service agencies. 


\section{Community Stakeholder Coalitions}

We learned how important it is to listen to community stakeholders' need for action as well as planning. We also were reminded of the need to highlight and celebrate small wins through the process, including acknowledging coalition members' participation in the coalition. Recruiting community coalition stakeholders required multiple approaches. For example, executive directors and agency heads frequently are asked to serve on many advisory councils. Thus, we reserved a steering committee role for these executive directors and focused on recruiting midlevel agency staff to do the coalition's day-to-day work; this served to strengthen agency capacity building through learning the skills needed to fully participate in the CTC process. To achieve broad community impact, this sometimes required slowing down the process to ensure we were building the local capacity needed to implement the chosen EPBs. Finally, we learned that youth and parents have competing priorities for their time and involvements. We did several things to include parents and youth. We created the expectation that community agencies would advocate on behalf of their clients to ensure parents' voices were amplified. We also linked with other organizations to communicate with and include youth and parents and to promote the use of the social development strategy. Lessons learned about stakeholder involvement and support will be important to addressing all of social work's grand challenges.

\section{Agency Capacity Building}

We discovered the need to build organizational capacity at the agency level to help agencies understand the value of the chosen evidence-based prevention programs and hence support implementation of the adopted EBPs. This included working with agencies to examine the fit of the EBPs into their existing service portfolio and to develop logic models for their other services. Through our resource assessment, we learned that there were many programs offered in the community (some with evidence of effectiveness and some without), there was little or no coordination, and these programs often were not sustained. To maximize impact, effective prevention programs that addressed priority risk and protective factors and had some community implementation history and acceptability were adopted with the intent to enhance implementation, sustainability, and expanded reach to the most vulnerable populations, thereby reducing disparities in prioritized outcomes. This required providing technical assistance with both the training and implementation of the EBPs in order to have enough qualified facilitators who reflected the community where the programs were being implemented. We also learned important lessons about the need to build financing capacity through leveraging new resources and redirecting existing resources to implement EBPs.

Although Communities in Action is just beginning to scale in a single community, the goal is to replicate this effort statewide. The importance of capacity build- 
ing to implement evidence-based programs at scale in a state also is illustrated in the experience of the state of Pennsylvania. Since 1999, Pennsylvania has been using the CTC model to build the capacity of communities; Pennsylvania State University provides backbone support to implement EBPs with a high degree of fidelity. By 2015, most counties in the state had a CTC community coalition and at least one evidence-based program in place. This has produced a $44 \%$ drop in the rate of juvenile delinquency dispositions. This delinquency decline translates into an \$85-million reduction in the cost of juvenile justice placements and resulted in the closure of three large youth correctional facilities and several short-term secure detention facilities, generating tens of millions of dollars in additional cost savings (Benedetto, Bumbarger, \& Kolchin, 2015; see Figure 4). This demonstrates that it is possible to achieve the Ensure Healthy Development for All Youth aspirational goal of a $20 \%$ reduction in behavioral health problems. It also demonstrates that the path from innovation to impact requires intentional capacity-building efforts that social work schools are well suited to provide.

\section{University-Community Partnerships}

The UW SSW learned that building strong university-community partnerships requires transparency about the goals of our work and being explicit about the mutual benefits and potential collective impact. We needed to serve as an active convener of this work. It was important to build community trust by demonstrating a long-term commitment to this under-resourced community. We also learned that it was important to involve social work students interested in prevention science to serve as a link between agencies and CTC workgroups. This required providing meaningful learning opportunities for practicum students. For example, we initially provided students with assessment and community organizing skills through the CTC process, coupled with micropractice opportunities through the coalition practicum agencies. In the program implementation years, we provided opportunities for students to be involved with the implementation of EBPs and to have opportunities to evaluate and provide programmatic feedback to agency leadership about evidence-based implementation. Schools of social work are poised to lead the way in promoting and implementing the grand challenges; efforts to promote university-community partnerships and opportunities for student involvement through practicum placements will promote strong workforce development for the next generation of social workers. This will require schools of social work to collaborate with communities, build strong partnerships, and stay committed and invested in long-term change.

The field of social work has accepted the Grand Challenge to Ensure Healthy Development for All Youth by Unleashing the Power of Prevention. This includes the seven action goals (described earlier) to accomplish this grand challenge at the local, state, and national level. Although strategies are needed to achieve the broad 


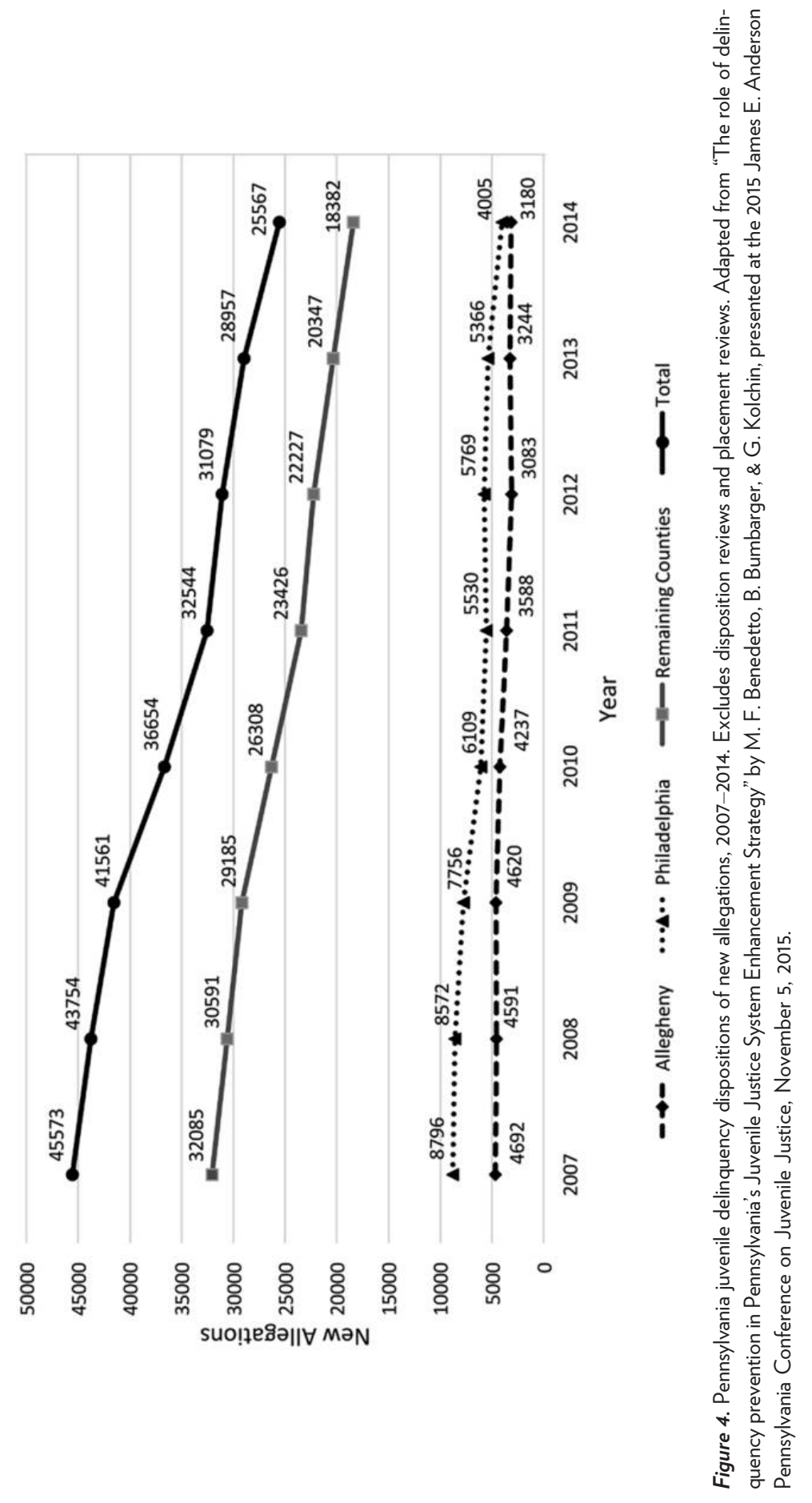

This content downloaded from 140.142.228.006 on February 15, 2017 08:44:48 AM 
goals of this grand challenge, Communities in Action is an example of a social work school taking innovative steps to meet this grand challenge at the local level and before seeking to scale the effort statewide. The UW SSW's support for this local implementation of the grand challenge has increased capacity in Southeast Seattle and Central Seattle. Collaborative efforts among community leaders, residents, practicum agencies, and UW SSW students are necessary steps to achieve local impact. The next steps will involve the community coalition working with system leaders and policymakers to reallocate resources so that public funds support the identified local prevention priorities. Communities in Action has provided a unique and valuable workforce development approach for Master of Social Work students, practicum agencies, and faculty.

\section{Author Notes}

Kevin P. Haggerty, MSW, PhD, is director of the Social Development Research Group and an associate professor in the School of Social Work, University of Washington.

Vaughnetta J. Barton, MSW, is project manager for Communities in Action, School of Social Work, University of Washington.

Richard F. Catalano, PhD, is the Bartley Dobb Professor for the Study and Prevention of Violence, Social Development Research Group, School of Social Work, University of Washington.

Margaret L. Spearmon, MSW, PhD, is a senior lecturer and Chief Officer of Community Engagement and Diversity, School of Social Work, University of Washington.

Edith C. Elion, MSW, is executive director of the Atlantic Street Center, Seattle, WA.

Raymonda C. Reese, MSW, is a mental health clinician at Therapeutic Health Services in Seattle, WA.

Edwina S. Uehara, MSW, PhD, is dean of the School of Social Work, University of Washington. Correspondence regarding this article should be directed to Kevin P. Haggerty, Social Development Research Group, School of Social Work, University of Washington, 9725 3rd Ave. NE, Suite 401, Seattle, WA 98115 or via e-mail to haggerty@uw.edu

\section{Conflict of Interest}

Kevin Haggerty is director of the Center for Communities That Care, which provides training and coaching to communities implementing the prevention system.

\section{References}

Aos, S., \& Drake, E. (2013). Prison, police, and programs: Evidence-based options that reduce crime and save money. Olympia, WA: Washington State Institute for Public Policy.

Aos, S., Lee, S., Drake, E., Pennucci, A., Klima, T., Miller, M., . . Burley, M. (2011). Return on investment: Evidence-based options to improve statewide outcomes (Document No. 11-07-1201). Olympia, WA: Washington State Institute for Public Policy.

Arthur, M. W., Hawkins, J. D., Pollard, J. A., Catalano, R. F., \& Baglioni, A. J., Jr. (2002). Measuring risk and protective factors for substance use, delinquency, and other adolescent problem behaviors: The Communities That Care Youth Survey. Evaluation Review, 26, 575-601. https://doi.org/10.1177/019384102237850 
Austin, D. M. (1983). The Flexner Myth and the history of social work. Social Service Review, 57, 357-377. https://doi.org/10.1086/644113

Benedetto, M. F., Bumbarger, B., \& Kolchin, G. (2015, November). The role of delinquency prevention in Pennsylvania's Juvenile Justice System Enhancement Strategy. Presented at the 2015 James E. Anderson Pennsylvania Conference on Juvenile Justice, Harrisburg, PA.

Berleman, W. C. (1980). Reports of the National Juvenile Justice Assessment Centers. Juvenile delinquency prevention experiments: A review and analysis. Washington, DC: U.S. Department of Justice, Law Enforcement Assistance Administration, Office of Juvenile Justice and Delinquency Prevention.

Blueprints for Healthy Youth Development. (n.d.). [Website]. Retrieved from http://www .blueprintsprograms.com/

Brown, E. C., Hawkins, J. D., Arthur, M. W., Briney, J. S., \& Fagan, A. A. (2011). Prevention service system transformation using Communities That Care. Iournal of Community Psychologv, 39, 183-201. https://doi.org/10.1002/jcop.20426

Campbell, F. A., Ramey, C. T., Pungello, E., Sparling, J., \& Miller-Johnson, S. (2002). Early childhood education: Young adult outcomes from the Abecedarian Project. Applied Developmental Science, 6, 42-57. https://doi.org/10.1207/s1532480xads0601_05

Catalano, R. F., Fagan, A. A., Gavin, L. E., Greenberg, M. T., Irwin, C. E., Ross, D. A., \& Shek, D. T. L. (2012). Worldwide application of the prevention science research base in adolescent health. Lancet, 379, 1653-1664. https://doi.org/10.1016/s0140-6736(12)60238-4

Catalano, R. F., Haggerty, K. P., Hawkins, J. D., \& Elgin, J. (2011). Prevention of substance use and substance use disorders: The role of risk and protective factors. In Y. Kaminer \& K. C. Winters (Eds.), Clinical manual of adolescent substance abuse treatment (pp. 25-63). Washington, DC: American Psychiatric Publishing.

Catalano, R. F., \& Hawkins, J. D. (1996). The social development model: A theory of antisocial behavior. In J. D. Hawkins (Ed.), Delinquency and crime: Current theories (pp. 149-197). New York, NY: Cambridge University Press.

Centers for Disease Control and Prevention, National Center for Injury Prevention and Control. (2014). Web-based Injury Statistics Query and Reporting System (WISQARS). Retrieved from www.cdc.govlinjury/wisqars

Clark, D. B., Cornelius, J. R., Kirisci, L., \& Tarter, R. E. (2005). Childhood risk categories for adolescent substance involvement: A general liability typology. Drug and Alcohol Dependence, 77, 13-21. http://dx.doi.org/10.1016/j.drugalcdep.2004.06.008

Coie, J. D., Watt, N. F., West, S. G., Hawkins, J. D., Asarnow, J. R., Markman, H. J., . . L Long, B. (1993). The science of prevention. A conceptual framework and some directions for a national research program. American Psychologist, 48, 1013-1022. https://doi.org/10.1037 //0003-066x.48.10.1013

DeVol, R., \& Bedroussian, A. (2007). An unhealthy America: The economic burden of chronic disease. Santa Monica, CA: Milken Institute.

Dodge, K. A., Bierman, K. L., Coie, J. D., Greenberg, M. T., Lochman, J. E., McMahon, R. J., \& Pinderhughes, E. E. (2015). Impact of early intervention on psychopathology, crime, and well-being at age 25. The American Journal of Psychiatry, 172, 59-70. https://doi.org/10.1176 lappi.ajp.2014.13060786

Fagan, A. A., Hawkins, J. D., Catalano, R. F., \& Farrington, D. P. (in press). Communities That Care: Prevention of youth violence, crime and substance abuse. New York, NY: Oxford University Press USA.

Farrington, D. P. (1995). The Twelfth Jack Tizard Memorial Lecture. The development of offending and antisocial behaviour from childhood: Key findings from the Cambridge Study 
in Delinquent Development. Journal of Child Psychology and Psychiatry and Allied Disciplines, 36, 929-964. https://doi.org/10.1111/j.1469-7610.1995.tb01342.x

Feinberg, M. E., Greenberg, M. T., Osgood, D., Sartorius, J., \& Bontempo, D. (2007). Effects of the Communities That Care model in Pennsylvania on youth risk and problem behaviors. Prevention Science, 8, 261-270. https://doi.org/10.1007/s11121-007-0073-6

Feinberg, M. E., Jones, D., Greenberg, M. T., Osgood, D. W., \& Bontempo, D. (2010). Effects of the Communities That Care model in Pennsylvania on change in adolescent risk and problem behaviors. Prevention Science, 11, 163-171. https://doi.org/10.1007/s11121-009 $-0161-\mathrm{x}$

Ferraro, F., Etzion, D., \& Gehman, J. (2015). Tackling grand challenges pragmatically: Robust action revisited. Organization Studies, 36, 363-390. https://doi.org/10.1177/0170840614563742

Haggerty, K. P., \& Shapiro, V. B. (2013). Science-based prevention through Communities That Care: A model of social work practice for public health. Social Work in Public Health. Special Issue: The Role of Social Work in the Prevention and Treatment of Substance Use Disorders, 28, 349 365. https://doi.org/10.1080/19371918.2013.774812

Hale, D. R., Fitzgerald-Yau, N., \& Viner, R. M. (2014). A systematic review of effective interventions for reducing multiple health risk behaviors in adolescence. American Journal of Public Health, 104, e19-e41. https://doi.org/10.2105/ajph.2014.301874

Hale, D. R., \& Viner, R. M. (2012). Policy responses to multiple risk behaviours in adolescents. Journal of Public Health, 34(Suppl 1), i11-i19. https://doi.org/10.1093/pubmed/fdr112

Harrop, E., \& Catalano, R. F. (2016). Evidence-based prevention for adolescent substance use. Child and Adolescent Psvchiatric Clinics of North America, 25, 387-410. http://dx.doi.org/10 .1016/j.chc.2016.03.001

Hawkins, J. D., Catalano, R. F., Jr., \& Associates. (1992). Communities That Care: Action for drug abuse prevention (1st ed.). San Francisco, CA: Jossey-Bass.

Hawkins, J. D., Jenson, J. M., Catalano, R., Fraser, M. W., Botvin, G. J., Shapiro, V., . . Stone, S. (2015a). A challenge to unleash the power of prevention (Commentary). Washington, DC: Institute of Medicine and National Research Council. Retrieved from https://nam.edu/perspectives -2015-a-challenge-to-unleash-the-power-of-prevention/

Hawkins, J. D., Jenson, J. M., Catalano, R., Fraser, M. W., Botvin, G. J., Shapiro, V., . . Stone, S. (2015b). Unleashing the power of prevention (Discussion Paper). Washington, DC: Institute of Medicine and National Research Council. Retrieved from https:/nam.edu/wp-content /uploads/2015/06/DPPowerofPrevention.pdf

Hawkins, J. D., Kosterman, R., Catalano, R. F., Hill, K. G., \& Abbott, R. D. (2005). Promoting positive adult functioning through social development intervention in childhood: Longterm effects from the Seattle Social Development Project. Archives of Pediatrics and Adolescent Medicine, 159, 25-31. https://doi.org/10.1001/archpedi.159.1.25

Hawkins, J. D., Kosterman, R., Catalano, R. F., Hill, K. G., \& Abbott, R. D. (2008). Effects of social development intervention in childhood 15 years later. Archives of Pediatrics and Adolescent Medicine, 162, 1133-1141. https://doi.org/10.1001/archpedi.162.12.1133

Hawkins, J. D., Oesterle, S., Brown, E. C., Abbott, R. D., \& Catalano, R. F. (2014). Youth problem behaviors 8 years after implementing the Communities That Care prevention system. A community-randomized trial. $\underline{\text { IAMA Pediatrics, }}$ 168, 122-129. https://doi.org/10.1001 ljamapediatrics.2013.4009

Hawkins, J. D., Oesterle, S., Brown, E. C., Arthur, M. W., Abbott, R. D., Fagan, A. A., \& Catalano, R. F. (2009). Results of a type 2 translational research trial to prevent adolescent drug use and delinquency: A test of Communities That Care. Archives of Pediatrics and Adolescent Medicine, 163, 789-798. https://doi.org/10.1001/archpediatrics.2009.141 
Hawkins, J. D., Oesterle, S., Brown, E. C., Monahan, K. C., Abbott, R. D., Arthur, M. W., \& Catalano, R. F. (2012). Sustained decreases in risk exposure and youth problem behaviors after installation of the Communities That Care prevention system in a randomized trial. Archives of Pediatrics and Adolescent Medicine, 166, 141-148. https://doi.org/10.1001 larchpediatrics.2011.183

Hawkins, J. D., Shapiro, V. B., \& Fagan, A. A. (2010). Disseminating effective community prevention practices: Opportunities for social work education. Research on Social Work Practice, 20, 518-527. https://doi.org/10.1177/1049731509359919

Hill, K. G., Bailey, J. A., Hawkins, J. D., Catalano, R. F., Kosterman, R., Oesterle, S., \& Abbott, R. D. (2014). The onset of STI diagnosis through age 30: Results from the Seattle Social Development Project intervention. Prevention Science, 15(Suppl 1), S19-S32. https://oi.org/10 .1007/s11121-013-0382-X

Hingson, R., \& White, A. (2014). New research findings since the 2007 Surgeon General's Call to Action to Prevent and Reduce Underage Drinking: A review. Iournal of Studies on Alcohol and Drugs, 75, 158-169. https://doi.org/10.15288/jsad.2014.75.158

Hoyert, D. L., \& Xu, J. (2012). Deaths: Preliminary data for 2011. National Vital Statistics Reports, 61(6). http://www.cdc.gov/nchs/data/nvsr/nvsr61/nvsr61_06.pdf

Janvier, R. L., Guthmann, D. R., \& Catalano, R. F. (1980). An assessment of evaluations of drug abuse prevention programs (Reports of the National Juvenile Justice Assessment Centers, NIJJDP). Washington, DC: U.S. Government Printing Office.

Kim, B. K. E., Gilman, A. B., Hill, K. G., \& Hawkins, J. D. (2016). Examining protective factors against violence among high-risk youth: Findings from the Seattle Social Development Project. Journal of Criminal Justice, 45, 19-25. https://doi.org/10.1016/j.jcrimjus.2016.02.015

Kuklinski, M. R., Briney, J. S., Hawkins, J. D., \& Catalano, R. F. (2012). Cost-benefit analysis of Communities That Care outcomes at eighth grade. Prevention Science, 13, 150-161. https:/l doi.org/10.1007/s11121-011-0259-9

Kuklinski, M. R., Fagan, A. A., Hawkins, J. D., Briney, J. S., \& Catalano, R. F. (2015). Benefit-cost analysis of a randomized evaluation of Communities That Care: Monetizing intervention effects on the initiation of delinquency and substance use through grade 12 . Journal of Experimental Criminology, 11, 165-192. https://oi.org/10.1007/s11292-014-9226-3

Lerner, R. M., Almerigi, J. B., Theokas, C., \& Lerner, J. V. (2005). Positive youth development: A view of the issues. The Iournal of Early Adolescence, 25, 10-16. https://doi.org/10.1177 /0272431604273211

Loeber, R., Farrington, D. P., Stouthamer-Loeber, M., \& Van Kammen, W. B. (1998). Antisocial behavior and mental health problems: Explanatory factors in childhood and adolescence. Mahwah, NJ: Lawrence Erlbaum Associates.

Lu, M. C., \& Halfon, N. (2003). Racial and ethnic disparities in birth outcomes: A life-course perspective. Maternal and Child Health Journal, 7, 13-30. http://dx.doi.org/10.1023/A:10225 37516969

Luthar, S. S. (2003). Resilience and vulnerability: Adaptation in the context of childhood adversities. Cambridge, UK: Cambridge University Press.

O’Connell, M. E., Boat, T., \& Warner, K. E. (Eds.). (2009). Preventing mental, emotional, and behavioral disorders among young people: Progress and possibilities. Washington, DC: National Academies Press.

Oesterle, S., Hawkins, J. D., Kuklinski, M. R., Fagan, A. A., Fleming, C., Rhew, I. C., . . . Catalano, R. F. (2015). Effects of Communities That Care on males' and females' drug use and delinquency 9 years after baseline in a community-randomized trial. American Iournal of Community Psychology, 56, 217-228. https://doi.org/10.1007/s10464-015-9749-4 
Stone, A. L., Becker, L. G., Huber, A. M., \& Catalano, R. F. (2012). Review of risk and protective factors of substance use and problem use in emerging adulthood. Addictive Behaviors, 37 , 747-775. https://doi.org/10.1016/j.addbeh.2012.02.014

Uehara, E., Flynn, M., Fong, R., Brekke, J., Barth, R. P., Coulton, C., . . W Walters, K. (2013). Grand Challenges for Social Work. Journal of the Society for Social Work and Research, 4, 165-170. http://dx.doi.org/10.5243/jsswr.2013.11

Van Pelt, J. (2009). Social work and public health-perfect partners. Social Work Today, 9, 28-31. Washington State Institute for Public Policy. (2016). Benefit-cost results [Website]. Retrieved from http://www.wsipp.wa.gov/BenefitCost?topicId5

Manuscript submitted: October 14, 2016 Revision submitted: November 9, 2016

Accepted: November 9, 2016

Electronically published: January 25, 2017 